\title{
Shalimar the Clown and the Politics of "Worlding" the Kashmir Conflict
}

\section{Sreyoshi Sarkar}

\section{(2) OpenEdition \\ 12 Journals}

Electronic version

URL: https://journals.openedition.org/ces/4731

DOI: $10.4000 /$ ces.4731

ISSN: 2534-6695

Publisher

SEPC (Société d'études des pays du Commonwealth)

\section{Printed version}

Date of publication: 1 September 2016

Number of pages: 23-33

ISSN: 2270-0633

\section{Electronic reference}

Sreyoshi Sarkar, "Shalimar the Clown and the Politics of "Worlding" the Kashmir Conflict",

Commonwealth Essays and Studies [Online], 39.1 | 2016, Online since 05 April 2021, connection on 07 December 2022. URL: http://journals.openedition.org/ces/4731 ; DOI: https://doi.org/10.4000/ces. 4731

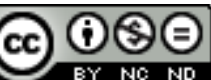

Creative Commons - Attribution-NonCommercial-NoDerivatives 4.0 International - CC BY-NC-ND 4.0 https://creativecommons.org/licenses/by-nc-nd/4.0/ 


\section{Shalimar the Clown and the Politics of "Worlding" the Kashmir Conflict}

This article analyzes Salman Rushdie's novel Shalimar the Clown and argues that while Rushdie's strategies of "worlding" produce a compelling "political elegy" (Mondal 31) of Kashmir and powerfully confront post-9/11 Islamophobia across the world, the problem lies in Shalimar's memorializing Kashmir as a tragic story of loss and violence. This elides the many ongoing, complex, stories of Kashmir - stories of conflict and suffering, but also people's struggles to survive, to rebuild, to heal homes and communities.

Violence is customarily conceived as an event or action that is $[\ldots]$ explosive $[\ldots]$ in space, and as erupting into instant sensational visibility. [However] we need [...] to engage [with] a different kind of violence, a violence that is neither spectacular nor instant, but rather incremental and accretive [...], the staggered and staggeringly discounted casualties, both human and ecological that result from war's toxic aftermath or climate change - [and which are] underrepresented in strategic planning as well as in human memory (Nixon 3). ${ }^{1}$

The Kashmir Valley, bordered to the north and west by Pakistan, to the east by China, and to the south by India, was once world famous for its pristine natural beauty, saffron fields, and hand woven carpets. ${ }^{2}$ In the last three decades it has been ravaged, trampled, and rendered destitute by conflicting nationalisms (Indian and Pakistani), and militant and military violence. ${ }^{3}$ Since the 1990 s, Kashmiris living in the Valley and elsewhere in the world have protested against these debilitating conditions by organizing mass rallies on the streets of Kashmir, in print, on film, and on social media sites such as YouTube, Facebook, and Twitter. ${ }^{4}$ However, their voices have only recently (in the last five to eight years), come to public notice because of a decade-long repression of such protests by the Indian state, and censorship by the national and international media. These protests do three important things. First, they challenge the fetishistic gaze of India, Pakistan and China, and their self-serving nationalist histories of Kashmir (Kabir 3). Second, they criticize the world's apathy to the "forgotten war" of Kashmir. Finally, they reclaim Kashmiri landscapes, histories, and political-cultural imaginaries, and rewrite

1. I would like to thank the reviewers at CES for their useful critical insights and Fiona McCann for her generosity and patience in helping me edit and revise this essay. I also owe a special word of thanks to Kavita Daiya, Melani McAlister, Patricia Chu, Victoria Barnett Woods, and Tawnya Ravy here at The George Washington University for their generous engagements with both argument and structure throughout this essay's many revisions.

2. Here "Kashmir," "the Kashmir valley" and "the valley" all refer to the Indian-occupied parts of Kashmir as opposed to Pakistan-occupied Kashmir, and China-occupied Kashmir (Akshai Chin). For a detailed historical background to Kashmir and the conflict see Mridu Rai (2004) and Victoria Schofield (2010).

3. It is important here to make a distinction between militants, insurgents and terrorists, since all three are often used loosely in the context of Kashmir but have specific and different meanings. Insurgency means rebellion against an oppressive force or an unjust establishment. In this chapter I use the "Kashmir insurgency" and the "Kashmir conflict" interchangeably; both refer to the encounters amongst the Indian military, armed militant groups, separatist political parties and local people in the three latter groups' protests against India's military occupation of Kashmir. While modes of protest and political agendas differentiate these insurgent groups, sometimes they have also been linked together in the context of Kashmir. When I say militants, I refer to radical Islamic fundamentalist groups who first emerged onto the Kashmiri political scene in the late 1980s. Their goal was to annex Kashmir to Pakistan because of its majority Muslim population.

4. See essay anthologies like Until Our Freedom Has Come: The New Intifada in Kashmir (Kak); creative-critical writing in Hindi by Meera Kant, in Urdu by Syeda Afshana, and in English by Salman Rushdie, Agha Shahid Ali, and Justine Hardy; and films like Haider (dir. Vishal Bhardwaj) amongst others. 
them through Kashmiri people's experiences of the conflict and their hopes for the future. A key strategy recently emergent in such rewritings has been that of "worlding" the conflict. In these, the Kashmir conflict is reimagined in conversation with other global contexts of state oppression and people's rebellion, like, for example, the Palestinian "intifada," the 2011 Arab Spring, and the 1989 Tiananmen Square protests in China. ${ }^{5}$ This destabilizes the dominant understanding of the Kashmir conflict as an internal political matter for India and Pakistan, and instead foregrounds the everyday struggles for survival by Kashmiris living in the conflict zone, highlights their subaltern modes of resistance against oppressive political regimes, and gives voice to the ways in which they imagine effective conflict resolution. Martin Heidegger first coined the term "worlding" in his 1927 book Being and Time. It stood for the experience of "being-in-the-world" or an ongoing process of relating to real life and time (Trend 2). Edward Said expanded on this idea in his book The World, the Text, and the Critic (1978). He noted that all texts are "worldly" in that they are produced as responses to real world politics and policies, as well as sociocultural dynamics that organize our worlds such as cultural ideals about love, or prescriptive gendered codes of behavior. These associations can be found in the setting of texts, the subjective positioning of authors, cultures of textual transmission, and interpretations of texts by diverse readers. More recently, Vilashini Cooppan has noted in her book Worlds Within (2009) that terms like "worlding" and "worldliness" are being increasingly used by postcolonial writers and theorists to "emphasize "coeval human cultural experiences that the elite European provenance of the term cosmopolitan forecloses"' (Cooppan qtd in Chakravorty 235).

In this essay, I engage with Indo-British author Salman Rushdie's processes of "worlding" (Said and Cooppan) in his postmodernist novel Shalimar the Clown (2005). I show how Rushdie is able to engender a complex history of the Kashmir conflict "from below" (Young 6) by reading the conflict in conversation with the Jewish genocide of World War II and the Rodney King race riots (1990s) in Los Angeles. This allows us to rethink the story of Kashmir from the ground up; as variously lived, felt, and remembered encounters amongst sentient and non-sentient subjects in the conflict zone. It also allows Rushdie to critically interrogate post-9/11 essentialist discourses that conflate terrorism with immigration and Islam (Morton 350). However, I also contend that Shalimar's overarching organization as a thriller narrative considerably compromises the novel's attempts at a critical history of the Kashmir conflict. This happens for two reasons. One, the demands of the thriller genre privilege spectacular forms of violence - terrorist, and pogrom violence - over more long-term and insidious forms of structural, gendered, and environmental violence. This produces a partial understanding of the lived experience of conflict violence. Two, the central plot of love, betrayal and revenge that organizes an otherwise heavily fragmented narrative, reproduces Kashmir as the fetishistic site of romance and adventure for South Asian and global audiences alike (Kabir 3). As such, Shalimar remains crucial yet limited in its interventions into hegemonic political and cultural discourses on Kashmir in contemporary times.

Salman Rushdie himself is of Kashmiri descent, his maternal grandfather lived in Kashmir and as a child he spent many a summer there with his family. An idyllic, peaceful Kashmir recurs in his writings including the Booker Prize winning Midnight's Children

5. See Sanjay Kak's “The Fire Is at My Heart: An Introduction” in Until My Freedom Has Come: The New Intifada in $\operatorname{Kashmir}(\mathrm{Kak})$. 
(1981) and Haroun and the Sea of Stories (1990). But Shalimar, conceived of as a response to both the world's apathy to the Kashmir conflict and the worldwide Islamophobia following the 9/11 terrorist attacks in New York City, is set for the most part in a war-ravaged Kashmir. Rushdie seeks to build towards a "sensate" (Butler 100) readership with Shalimar. As he notes in his PBS interview (2006) with Bill Moyers, "one of the things in the time we live in, is that there is a kind of imaginative failure, of understanding across the gulfs in the world [...]. So now I find myself [...] trying to tell stories which explore how different bits of the world join up." In Shalimar we are therefore given a "worlded" chronotope as Rushdie attempts to globalize the Kashmir conflict by interweaving his Kashmiri protagonists' lives with those of Holocaust survivors and "the human bloat" (Rushdie 378) of Los Angeles immigrants.

The novel opens with the murder of the US counterterrorism chief, Max Ophuls, by his driver, Shalimar, right on the doorstep of his daughter India's condo in Los Angeles. This is followed by a flashback to the Kashmir of the 1940s-1990s where we realize that Shalimar's motive for murder is personal rather than political. By profession, Shalimar is a clown performing the tightrope sequence in his father's village theater group called the "bhand pathers" (61) in Pachigam, Kashmir. Max Ophuls, the Holocaust survivor and resistance hero of WWII goes to Kashmir during the 1960s as the U.S. ambassador to India. Here he (despite being married to his Jewish Resistance partner Peggy Rhodes) falls in love with Shalimar's wife Boonyi. A torrid affair ensues between the two for a few months ending badly for both. Max is vilified in both Indian and international media, and has to resign from active service; Boonyi is ostracized by the village; and their illegitimate daughter, India, is forcibly taken away to London by Rhodes. The rest of the novel follows Shalimar as he sets out to avenge his "injured manhood" and kill Max.

With the publication of Midnight's Children in 1981, Rushdie was hailed as a vanguard of the postmodernist movement (Hutcheon, Hassumani, Connor). Shalimar too is organized along a postmodernist aesthetics of fragmentation, rapid temporal-spatial shifts, and magic realism. The bildungsroman or the linear narrative of the central protagonist Shalimar is constantly disrupted by a back and forth movement between the past and the present, and between L.A., Kashmir, and Strasbourg. Allegory is central to the novel's gendered critique of India's occupation of Kashmir and the U.S.-Vietnam war. However, Shalimar is not a "national allegory" (Jameson 69) in the manner of Midnight's Children. Instead it is primarily a "political thriller" (Miller) that shows how its protagonist Shalimar metamorphoses from the local theater clown to a trained terrorist. However, unlike conventional fast-paced thrillers, Shalimar is about four hundred pages long, in small print, and its vigilante plot and action are constantly interrupted by stories of the socio-political tensions pervading Kashmir and Pachigam, and the life stories of both central and minor characters.

Shalimar's strategies of "worlding" usefully disrupt the linearity of time, and official history, to foreground "counter-histories" (Choudhuri 13) of lived experience. Characters and events are connected across time and space via "textual parallels and mirroring strategies" (Choudhuri 14). Thus Max, Shalimar, and India are connected by their desires for revenge and through Boonyi. As each character sets out to set things right, we experience life and time as continuous cycles of revenge and narrative closure is refuted. This gestures at alternative experiences of time and history for different people within shared landscapes. 
"Everywhere was a mirror of everywhere else. Executions, police brutality, explosions, riots: Los Angeles was beginning to look like wartime Strasbourg; like Kashmir [...]. Stores were looted, cars were torched, there were fires everywhere" (355-6). Analogies like this are seminal sites of "worlding" in Shalimar. Herein the past and present as distinct categories, and First World-Third World hierarchies, are broken down. Discourses of civilizational progress in time, or of the U.S./Global North being more peaceful and civilized than unstable nation-states of the Global South are swiftly dismantled through the double simile signaled by the word "like" as ethnic, racial, and political forms of violence are shown to be the norm across the world in the $20^{\text {th }}$ and $21^{\text {st }}$ centuries. Florian Stadtler further notes that such analogies "complicate the novel's debates about terrorism by raising the question of whether there is a difference between state-led terror and terrorism by militants" (196).

Yet these critical histories that Shalimar highlights, I contend, become constantly enervated by the novel's investments in only the spectacular episodes of violence in the valley. The fictional village of Pachigam in the novel is home to the "bhand pather" or the travelling players of Kashmir. It stands for a Kashmir of the people. As Stephen Morton notes, Pachigam is Rushdie's answer to the self-serving accounts of Kashmir harbored and fed to the domestic and international media by both India and Pakistan, each sovereign nation claiming Kashmir for itself (349). However in Shalimar, the history of Kashmir becomes reclaimed and re-narrated as the people of Pachigam experience it - through rumors, fear (131), "bad omens" (72) and "forebodings" (72). They also shape it, for instance through Boonyi's agency as Max's lover in "shaping American diplomatic policy on Kashmir," or the Pachigamis' defiance of the sacrosanct international border between India and Pakistan - the Line of Control (LoC) - by contemptuously walking across it for everyday personal needs or pleasure "whenever they so chose" (97). ${ }^{6}$ Finally "Kashmiriyat," the "regional spirit of communal harmony and cultural syncretism" (Siddiqi 295), is fostered in the village through everyday practices as opposed to being being a fixed ideology or a textbook mode of communal life that people blindly follow. As such, the villagers overlook religious and political differences to bond with each other through activities like storytelling, gossiping, cooking, and theatrical performances. This practiced "Kashmiriyat" is at the core of the novel's political imagination of "azadi" (freedom) for Kashmir: "Its inhabitants had come to the conclusion that they didn't much like India and didn't care for the sound of Pakistan. So: freedom! Freedom to be meat-eating Brahmins or saint-worshipping Muslims, to make pilgrimages to the ice-lingam high in the melting snows or to bow down before the Prophet's hair in a lakeside Mosque, [...] Azadi! Paradise wanted to be free" (253).

But this conception of Kashmir as a "vernacular cosmopolitan" community by Rushdie ends up romanticizing Pachigam as an idyllic space. Class and religious differences exist but "are muted by commonality and mutual respect." Internal tensions and hostilities are sidelined to focus on "the external forces that threaten its integrity" (Siddiqi 297). No negativity is allowed to exist within the boundaries of the village. The toxic Indian military encampment of Elasticnagar is located at a distance from Pachigam, the Islamist fundamentalist leader Maulana Bulbul Fakh finds a following, however temporary, in neighboring Shirmal village but never in Pachigam, the "bhand pathers" of

6. The LoC or the Line of Control is the military control line between the India-occupied parts of the valley of Kashmir (known as state of Jammu \& Kashmir) and Pakistan-occupied parts of Kashmir (known as Azad Kashmir). 
Pachigam perform on stage in Srinagar while the rest of the city protests against Indian military occupation on the streets outside the theater. All rapes, suicides, murders and bloodshed happen outside Pachigam until the very end.

Subsequently, the destruction of the village is mythicized within a particular dynamics of cosmic violence wherein "Pachigam was the earth, the grabbee, helpless, and powerful uncaring planets stooped low, extended their celestial and merciless tentacles and grabbed" (Rushdie 308). Magic realism further secures this connection. While the Kashmiri Pundits are being forced out of their homes at gunpoint by Islamic terrorists, Boonyi's father Pundit Pyarelal dressed in his wedding attire calls upon and embraces his own death sitting under the apple tree in his garden amidst pastoral resplendence. Shalimar's mother Firdaus Noman's snake curse calls upon a multitude of snakes whose bites finally kill General Kachhwaha thereby avenging the fall of Pachigam at the hands of the Indian army. And the cuckolding, outcast Boonyi develops an "anti-love" soul connection with Shalimar owing to the latter's intense hatred of her that enables them to communicate with each other across great distances.

As a result of this continual consecration of Pachigam by cosmic, mythical and magical forces, its violent end during the Indian military crackdown literally acquires the proportions of the Biblical Fall. This is reinforced by the narrator's simultaneous commendation of and mourning for Pachigam, or Kashmir within the narrative itself:

[...] for where Pachigam once stood by the blithe Muskadoon, where its little street ran along from the pandit's house to the sarpanch's, where Abdullah roamed and Boonyi danced and $[. .$.$] nothing resembling a human habitation remains. What happened that$ day in Pachigam need not be set down here in full details, because brutality is brutality and excess is excess and that's all there is to it. (309).

This narrative praxis of simultaneous witnessing and mourning performs a scathing critique of both the sovereign Indian occupation of Kashmir and terrorist violence. Even as it resists the voyeuristic - "There are things that must be looked at indirectly" (309) - it invokes the heft of the spectacular in the sudden break with the continuity of the almost Edenic life described in the first line. The alliteration ("human," "habitation") and the repetition of "brutality" and "excess" reinforce the catastrophic nature of the violence that destroyed the village. This is further reified when the story itself moves away from Kashmir at this point. L.A. not only becomes the new site of action (with Shalimar planning and executing the murder of Max) but also the focus site of the rest of the novel. It's almost as if once Pachigam as the crucible of Kashmiriyat has been razed to the ground, there is nothing else of value to talk about in Kashmir, no other kind of community or agency imaginable in the war-torn landscape. This is borne out towards the end when India visits Kashmir to find out what really happened to her outcast mother Boonyi. She stays with Yuvraj (a rich Kashmiri-Punjabi exporter of handicrafts to the West). His mansion is a walled structure of grandiose proportions that blocks out sounds of "marching feet, clenched-fist demands" (359). But when the two visit Pachigam together they are forced to confront

[...] giant burrowing creatures, ants or worms, [that] had wiggled up from underground and built a colony of earthworks in a graveyard. The ruins of the old village were still visible $[\ldots]$ and around and in between these ghosts new dwellings had sprung up, ramshackle hovels of sticks and earth and moss thrown together without any evidence of care or thought, [...] "the slovenly products of an inferior species," Yuvraj called them, sounding angry, "or our own kind, regressing towards savagery." (362) 
Yuvraj has had no prior interaction with these nameless "creatures" - the refugee squatters now living amongst the ruins of Pachigam. Yet he immediately calls them out as guilty and suspect. Even before Yuvraj, the third person omniscient narrator has already dehumanized them by calling them "giant burrowing creatures, ants or worms." Here, as in Liisa Malkki's Purity \& Exile (1995), the displaced subaltern body, the refugee subject, is read as apolitical, de-historicized and enervated, an unsubstantial presence that does not have a credible narrative of experience and/or lacks the language/means of delivering such testimonies. It is not just the humans who are disparaged; all material histories and testimonies are also negated and dismissed. As such, the "old village" of Pachigam is referred to as "ruins" - the word reinscribing its historical-cultural value even in its broken down state. In contrast, the "new" houses are devalued and dismissed as "earthworks" in a "graveyard"; marked as shifty and suspect for having "sprung up" "in between" and "around" the ruins of the "original" houses. This verbal desecration continues in the rest of the paragraph. In the process, any testimonies that the patched together "hovels" might have offered - owners' labors in constructing them, their efforts at survival amidst the violence, the ongoing-ness of the conflict itself - become easily elided and misread as evidence of the "new" people's failure - their lack. These lines do highlight the refugees' plight and remind readers that Kashmir continues to be in the throes of this decimating violence. But not for long.

Yuvraj's words quickly obfuscate and sideline the suffering people and landscapes: "Something has happened here that is not good I fear" (362). "Something" in its inaccuracy and vagueness, its refusal to name the attritional violence of the conflict and its toll on the people and the environment, renders these stories insignificant and unspeakable. They are further condemned for not being the "original villagers" and for having "seized land that is not theirs" (362). In all of this the novel never allows the refugees to speak for themselves. Instead, having spurned them in the above ways it quickly moves on to the "more credible native" (362): Hasina Yambarzal's narrative of Boonyi's last days. ${ }^{7}$ Therefore, even as Shalimar seeks to raise public consciousness on the Kashmir insurgency, it remains limited in doing this by its preference for narrating the conflict primarily through the highly visible violence - the Indian army destroying Pachigam, killing and raping men, women and children, and Shalimar's militant group being ambushed and killed by the villagers of Shirmal. The stories of "precarious lives" (Butler 3) and of "slow violence" (Nixon 3) that constitute the lived realities of Kashmir become marginalized in the novel as its veneration of an uncritical cosmopolitan community in Pachigam determines what makes for meaningful communities and useful praxes of global coexistence.

The conflict violence is discussed in more nuanced ways in the novel's "worlding" of the three acts of genocide it describes. The first is the Jewish Holocaust which takes away the lives of Max's parents in 1940s Strasbourg. The second is the terrorizing, murder, and forced exodus of the Hindu Kashmiri Pundits by Islamic terrorist organizations backed by the Pakistani Inter-Services Intelligence (ISI) in 1989. The third is the harassment and incarceration of local Kashmiri Muslim populations by Indian army

7. In the novel Hasina Yambarzal is a friend of Shalimar's mother and Boonyi's mother-in-law, Firdaus. She is the wife of the headman of Shirmal village as well - the village that managed to survive the terrorist attack on it through the sheer ingenuity of its people. Thus, she stands for "original villagers," and her narrative also gains credibility from her higher position in the village hierarchy. 
personnel under orders of the Indian "political echelon" (Rushdie 146). Although not labeled "genocide" the two latter episodes are clearly referred to in the novel as being of the same caliber and intent as the Holocaust, given the terms in which the target populace is marked for annihilation. The Kashmiri Pundit exodus is labeled "ethnic cleansing" (265) while the Indian government's orders to its armed forces stationed in Kashmir is: "Every Muslim in Kashmir should be considered a militant. The bullet was the only solution" (291).

The aesthetics of mourning the resulting military crackdown on Pachigam further connects the two Kashmiri genocides. Pachigam's destruction is mourned by the third person narrator in the text via questions that witness and critique the military evisceration of the village. "Who lit that fire? Who burnt that orchard [...] Who clubbed that grandmother [...] Who raped that dead woman? Who raped that dead woman again?" (308). Here spectacular reproductions of the violence become intercepted and undercut by the "Who" and by the question format of the above lines. As Yumna Siddiqi notes, speaking of the "genocide" in questions as opposed to statements underlines the "representational limits of language" (305); it shows the importance of bearing witness, yet the difficulty of speaking its horrors. The persistence of the questions underscores that such violence can never be forgotten or forgiven. This is repeated in the novel's critique of the Kashmiri Pundit exodus. The third person omniscient narrator in Shalimar condemns it in the following words:

There were six hundred thousand Indian troops in Kashmir but the pogrom of the pandits was not prevented, why was that. Three and a half lakhs of human beings arrived in Jammu as displaced persons and for many months the government did not provide shelters or relief or even register their names, why was that. (296).

Here, each sentence, although a question, ends with a full stop. This only heightens the pathos of the situation - the full stop signaling the narrator's non-expectation of any answers. That is how hopeless the condition of the refugees is. No one cares about their suffering, nobody will even try and be accountable for what happened to them or their difficult lives in ill-equipped refugee camps across India. As Kavita Daiya points out, here Shalimar does two important things: first, it performs a crucial intervention in "normative narrations of nationalist" accounts of the Kashmir conflict by witnessing and protesting against the often-erased episode of the forced exodus of Kashmiri Pundits. Second, it makes visible and "relentlessly" calls out the Indian state's failure and apathy towards protection and rehabilitation of displaced Kashmiris (205). In effect, it returns attention to the continuing "slow violence" of the exodus and its victims as opposed to reactionary debates in public and political spheres that are more interested in returning to the originary spectacular event of the exodus in order to fix blame on Kashmiri Muslims or the Indian government for allowing such violence to happen in the first place. This aligns the novel not just with counter-public articulations of "subaltern presents" but also marks its narrative performance of "witnessing" as seminal to uncovering "the violent empire[s] of nation-states and how states can generate unbelonging" (Daiya 205-6).

Building on Daiya's and Siddiqi's analyses of memory and witnessing, I argue that Rushdie's project to memorialize Kashmiri suffering through references to the Jewish Holocaust is nevertheless problematic. This is because it ends up shaping our affective responses to the Kashmiri "genocides" primarily through our encounters with the 
Holocaust in the novel, and by extension, through our knowledge of the Holocaust as it circulates in the socio-cultural spaces we negotiate (books, films, documentaries and other media representations, our own Jewish acquaintances and friends, and their memories/interpretations of the Holocaust). In Postcolonial Witnessing, Stef Craps talks about the dangers of centering the Holocaust as a moral touchstone for other experiences of genocide. He agrees with Daniel Levy and Natan Sznaider that evoking the context of the Jewish Holocaust might make a stronger case for human rights violations and pressure world communities towards immediate intervention and reparation in the said conflict zone. But he also underscores how evoking the Holocaust often elides the complexities of a particular incident of genocide.

In Shalimar, the Kashmiri genocides are directly linked in their imaginative and affective energies with the Jewish Holocaust. "Loot, plunder, arson, mayhem, murder, exodus: these words recurred day after day, and a phrase from another part of the world that had flown many thousands of miles to find a new home in Kashmir. "Ethnic cleansing"' (295). This immediately recalls the only other instance of "ethnic cleansing" that comes before this point in the novel - the brief account of the Jewish Holocaust we get in the preceding chapter "Max" wherein we learn how Max's parents are picked up by Nazi soldiers and taken to the gas chambers while Max himself manages to escape their fate. The above quoted line thus directly connects the organized annihilation of Hindu Kashmiri Pundits in the valley to the Holocaust. Max Ophuls himself makes the associations clear several times. On first noticing Boonyi dancing at a cultural function in Kashmir, Ophuls is reminded of the "feathered dead-eyed showgirls wreathed in Nazi cigar smoke, flaunting their gartered thighs [...]" (140). Here Ophuls is aware of Boonyi's purposeful seduction of him for material gains yet he does not condemn Boonyi or the "showgirls" in any moral sense because he recognizes their entrapment by circumstances and gendered social roles. The passive voice in the first part of the sentence ("feathered," "dead-eyed" and "wreathed in") underscores the displacement of agency of seduction from the showgirls onto the political circumstances. This undercuts their agency and intent as suggested by "flaunting their gartered thighs." Ophuls' and the novel's critique of this kind of gendered violence becomes further reinforced by the next line of the paragraph wherein Ophuls refers to Boonyi and the showgirls as "survivors." This aligns them to his own status as survivor of ethnic-political violence of the Holocaust. While standing at the ceasefire line (LoC) on the Indian-occupied Kashmiri side, Max's thoughts again foreshadow the genocides to come in Kashmir, connecting them directly to his own and his people's experiences during the Nazi regime:

Then his history reasserted itself $[. .$.$] in particular the history of his hometown, and$ the whiplash movements of the Franco-German frontier across its people's lives. He had come a long way but perhaps not so very far. Could any two places have been more different, he asked himself; could any two places have been more the same? (180)

Reimagining the "frontier" (here both the LoC and the Franco-German border) in such an uncanny fashion - as alive and "lashing out" - forces readers to pay attention to the politics of how borders are determined, constructed, and how they affect people's lives and livelihoods. This disrupts our general apathy towards and compliance with hegemonic cartographies. Moreover, since Ophuls' particular experience of place - the LoC - produces analogies between Kashmiri and Jewish histories, it foregrounds for us peoples' histories - their narratives of place and time as experienced by them and their 
ancestors as opposed to official History that inevitably focuses on the developmental narrative of the nation-state.

Such associations of Kashmiri history with that of the Holocaust undoubtedly make the Kashmir conflict more accessible, through analogy, to global audiences unfamiliar with the subject. The aim of "worlding," here reading the genocide-like violence in Kashmir in critical conversation with the Jewish Holocaust, could very well be effective in shocking readers into recognizing that holocaust-like episodes continue to happen in the twenty-first century. This might even rally them to definitive action or activism for urgent redress of the Kashmir conflict. However, the cultural authority of the Holocaust also derives from its past-ness and the terrifying pain and suffering of the six million Holocaust victims. That, I argue, overtakes the narrative here. While the novel highlights through its witnessing and mourning the complex interconnected natures of the killing sprees in the valley, the affective overshadowing of the Holocaust continually directs us to feel the paralyzing horror of what the Pundits and the Pachigamis undergo at the hands of their murderers. While that should have been a jumping off point for protest and action, I contend that instead it numbs us into grappling with the bare humanity and raw suffering of the Kashmiris who were victims of military and militant pogroms. This obfuscates important critiques of postcolonial projects of violent nation-makings that Shalimar begins to make. It also underscores the primacy of immediate and calamitous kinds of violence "that [are] newsworthy because [...] event focused, time bound and body bound" (Nixon 3) for the novel's imagination of Kashmir at the cost of damages that might not demand an immediate redress, being dispersed gradually over time and space. Thus while Shalimar notices the new inhabitants, and draws attention to the continuing suffering of exiled Kashmiri Pundits across India, these stories are constantly subsumed within the novel's investments in the spectacular history of the conflict.

Shalimar is jailed for Ophuls' murder, stands trial, and is given the death penalty. In jail he receives angry letters from India vowing to kill him and avenge her father's death. As with Boonyi, he and India become connected telepathically through an intense hatred of each other. In the last chapter, Shalimar escapes from prison and heads to India's estate. He breaches her security system, and the last line of the novel leaves us with the two adversaries facing each other in what will be a battle unto death.

Stephen Morton underscores how the "singularity of the Kashmir conflict" becomes elided in Shalimar's racial profiling in the U.S. where, post-9/11, the different nodes of Shalimar's identity, namely immigrant, Muslim, and murderer are collapsed into the definitive label of the "terrorist." This despite the fact that his murder of Max is entirely motivated by a personal agenda - his wife Boonyi's betrayal of him with her lover Max. But the "real" story about Shalimar cannot be heard in a U.S. judicial-political space, especially when the police in their search for the murderer trace Shalimar's connections to militant terrorist outfits in the Philippines, in Pakistan, and in Kashmir. Neither does it help that Max happened to be the U.S. counterterrorism chief at the time of his murder. But if the U.S. state as sovereign power performs such elisions of the immigrant Muslim subject then, I argue, Rushdie's narrative too compromises a critical representation of its subject - Kashmir. This is because in spite of Shalimar's considerable attempts at foregrounding "counter-histories" of the Kashmiri people, its investments in the thriller genre, in spectacular conflict violence, and mourning an 
"original" Kashmir symbolized by the magical village of Pachigam foreclose attention to all other emergent narratives from sites of "slow violence" in Kashmir in the novel. Consequently, once Pachigam is razed to the ground, Kashmir becomes a thing of the past in the narrative - a tragic memory of Paradise lost forever to unrelenting violence. Stories of its current inhabitants are suspect even as lines such as "She no longer saw this as an American story. It was a Kashmiri story. It was hers" (372) and "There was no India. There was only Kashmira, and Shalimar the clown" (398) reiterate the novel's insistence on an intrinsic connection between original inhabitants of Pachigam and a credible story about Kashmir. Here Shalimar is the "original" inhabitant of Pachigam while India/Kashmira as Boonyi's daughter is authorized to "own" the story of Kashmir - that is claim and make her own story the story of Kashmir. ${ }^{8}$ The above lines undoubtedly reclaim Shalimar's story from the archive of U.S. terrorism narratives, show us that there are alternative perspectives and accounts of terrorism and terrorist agendas possible, seek to humanize terrorists, reimagining them as autonomous "grievable subjects," (Butler 32) and remind us to critically interrogate India's nationalist narratives of Kashmir. However, in asserting that the story of Kashmir can ultimately only be about Shalimar's and India's mutual confrontation and vengeance, it reifies the story of Kashmir as a thriller narrative - a story of love, betrayal, and revenge. Kashmir thus becomes reinscribed within Orientalist discourses about the East as site of romance, adventure, excessive emotions, and thrills for Western and South Asian audiences alike (Said 200-8).

To conclude, while Rushdie's strategies of "worlding" produce a compelling "political elegy" (Mondal 31) of Kashmir and powerfully confront post-9/11 Islamophobia across the world, I argue that the problem lies in Shalimar's memorializing Kashmir as a tragic story of loss and violence. This elides the many ongoing, complex, stories of Kashmir - stories of conflict and suffering, but also people's struggles to survive, to rebuild, to heal homes and communities. As Veena Das and Arthur Kleinman remind us in Violence and Subjectivity, "the moment of destruction is but one moment; hence [it becomes essential to attend to] the manner in which processes of resistance, contestation and accommodation begin to happen but without looking for miraculous exceptions and hopeful endings" (qtd in Kumar 176).

Sreyoshi SARKAR

The George Washington University

\section{Works Cited}

BAHri, Deepika. "Disembodying the Corpus: Postcolonial Pathology in Tsitsi Dangarembga's Nervous Conditions." Postmodern Culture: An Electronic Journal of Interdisciplinary Criticism. 5.1 (1994): 1-59.

Butter, Judith. Precarious Life: The Powers of Mourning and Violence. London and New York: Verso, 2004. —. Frames of War: When is Life Grievable? New York: Verso, 2009.

8. Here we are reminded that India at birth was named "Kashmira" by Boonyi - India's birth mother. But when Max's wife Peggy Rhodes snatches up the baby girl from Boonyi for her own, she renames Kashmira as India, in order to erase all traces of her connection to Boonyi and Max's affair with her. The political-cultural quarrels between India and Kashmir herein become displaced onto the privileged, mixed heritage, female, U.S. citizen-subject. This is problematic given how it threatens to erase local Kashmiri voices from the discourse and the feminization of both India and Kashmir. A more detailed discussion, though important, is beyond the scope of the current essay. 
Chakravorty, Mrinalini. In Stereotype: South Asia in the Global Literary Imaginary. New York: Columbia UP, 2014.

Choudhuri, Sucheta M. "'Death was not the End': Resentment, History and Narrative Structure in Salman Rushdie's Shalimar, the Clown." Otherness: Essays and Studies. 2.1. n.p. August 2011. 26 December 2014 <http://www.otherness.dk/fileadmin/www.othernessandthearts.org/ Publications/Journal_Otherness/Otherness_Essays_and_Studies_2.1/5.Sucheta_Choudhuri. pdf $>$.

Connor, Steven. "Postmodernism and Literature." The Cambridge Companion to Postmodernism. Ed. Steven Connor. UK: Cambridge UP, 2004. 62-81.

Cooppan, Vilashini. Worlds Within: National Narratives and Global Connections in Postcolonial Writing. Stanford: Stanford UP, 2009.

Craps, Stef. Postcolonial Witnessing: Trauma Out of Bounds. New York: Palgrave Macmillan, 2013.

DAIYA, Kavita. Violent Belongings: Partition, Gender, and National Culture in Postcolonial India. Philadelphia: Temple UP, 2008.

DAs, Veena. Life and Words: Violence and the Descent into the Ordinary. Berkeley: U of California P, 2007.

Haider. Dir. Vishal Bhardwaj. Perf. Shahid Kapoor, Shraddha Kapoor, TABU et al. UTV, 2014.

Hassumani, Sabrina. Salman Rushdie: A Postmodern Reading of his Major Works. Madison, Teaneck: Fairleigh Dickinson UP, 2002.

Hutcheon, Linda. A Poetics of Postmodernism: History, Theory, Fiction. New York: Routledge, 1988.

Jameson, Frederic. "Third-World Literature in the Era of Multinational Capitalism." Social Text 15 (Autumn 1986): 65-88.

KaBIR, Ananya Jahanara. Territory of Desire: Representing the Valley of Kashmir. Minneapolis: U of Minnesota P, 2009.

KaK, Sanjay. "Introduction." Until My Freedom Has Come: The New Intifada in Kashmir. Ed. Sanjay Kak. Chicago, IL: Haymarket Books, 2013.

Kumar, Priya. Limiting Secularism: The Ethics of Coexistence in Indian Literature and Film. Minneapolis: U of Minnesota P, 2008.

Malkki, Liisa H. Purity and Exile: Violence, Memory, and National Cosmology among Hutu Refugees in Tanzania. Chicago: U of Chicago P, 1995.

Miller, Laura. "Shalimar the Clown: An Assassin Prepares." The New York Times. 23 October 2005.

Mondal, Anshuman A. "Bad Faith: The Construction of Muslim Extremism in Ed Husain's The Islamist." Culture, Diaspora, and Modernity in Muslim Writing. Ed. Rehana Ahmed, Peter Morey, and Amina Yaqin. New York and London: Routledge, 2012.

MorTOn, Stephen. "'There were collisions and explosions. The world was no longer calm.' Terror and Precarious Life in Salman Rushdie's Shalimar, the Clown." Textual Practice. 22.2. (2008): 337-55.

Nixon, Rob. Slow Violence and the Environmentalism of the Poor. Cambridge, MA.: Harvard UP, 2011.

RaI, Mridu. Hindu Rulers, Muslim Subjects: Islam, Rights, and the History of Kashmir. Princeton, N.J.: Princeton UP, 2004.

Rushdie, Salman. Shalimar the Clown: A Novel. London: Jonathan Cape, 2005.

—. Interview by Bill Moyers. "Bill Moyers on Faith and Reason". PBS, 23 June 2006. 11 January 2015. <http://www.pbs.org/moyers/faithandreason/print/faithandreason101_print.html>.

SAID, Edward W. The World, the Text, and the Critic. Cambridge, MA: Harvard UP, 1983.

Schofield, Victoria. Kashmir in Conflict: India, Pakistan and the Unending War. London: I. B. Tauris, 2010.

SIDDIQI, Yumna. "Power Smashes into Private Lives': Violence, Globalization and Cosmopolitanism in Salman Rushdie's Shalimar the Clown." South Asia Research. 27.3 (2007): 293-309.

STADTLER, Florian. "Terror, Globalization and the Individual in Salman Rushdie's Shalimar the Clown." Journal of Postcolonial Writing. 45.2 (2009): 191-9.

Trend, David. Worlding: Identity, Imagination, Media in a Digital Age. New York: Routledge, 2016.

Young, Robert J. C. Postcolonialism: A Very Short Introduction. New York: OUP, 2003. 